\title{
MŁODOPOLSKIE KRYMINAŁY Z GALICJĄ W TLE, CZYLI MARYLI SZYMICZKOWEJ SPOSÓB NA KRYMINAŁ RETRO
}

\author{
Anna Podstawka \\ Katolicki Uniwersytet Lubelski Jana Pawła II \\ Lublin, Polska \\ ORCID: 0000-0002-4681-9770
}

\begin{abstract}
YOUNG POLAND'S CRIME STORIES SET IN GALICIA MARYLA SZYMICZKOWA'S RETRO CRIME NOVELS
\end{abstract}

\begin{abstract}
Retro crime novels, set at the turn of the 20th century or in the interwar period, have recently become one of the most popular trends in Polish criminal literature. Throughout the latest years among the most interesting literary phenomena stands out a series of retro crime novels by Jacek Dehnel and Piotr Tarczyński, published under the pseudonym of Maryla Szymiczkowa. The trilogy: Tajemnica Domu Helclów (2015; English edition Mrs Mohr Goes Missing, 2019), Rozdarta zastona (2016) and Seans w Domu Egipskim (2018) inscribes itself in the criminal literature set in the far past, and at the same time it plays with the pop-cultural convention, drawing extensively on various literary sources and recreating a colourful image of modernist culture and the socio-historical reality of the 19th century Galicia.
\end{abstract}

Key words: retro crime novels, Maryla Szymiczkowa, Jacek Dehnel, Piotr Tarczyński.

Literatura sensacyjna i kryminalna, obejmująca szeroki zakres tematów i problemów, a także sposobów konstrukcji i narracji, promowana przez działania popularyzatorskie (m.in. portale internetowe) oraz poważnie wspierana przez badania literaturoznawcze i akademicką krytykę literacką, należy do najbujniej rozwijających się nurtów współczesnej kultury ${ }^{1}$. Największą grupę polskich kryminałów ostatnich lat tworzą te, które można nazwać powieściami detektywistycznymi albo też detektywistyczno-obyczajowymi - stwierdza

1 Zob. m.in. A. Martuszewska, Ta trzecia. Problemy literatury popularnej, Gdańsk 1997; eadem, Radosne gry. O grach / zabawach literackich, Gdańsk 2007; M. Czubaj, Etnolog w Mieście Grzechu. Powieść kryminalna jako świadectwo antropologiczne, Gdańsk 2010. Poza tym należy odnotować systematycznie powiększającą się liczbę tomów zbiorowych i publikacji pokonferencyjnych, np. Kryminat. Między tradycją a nowatorstwem, „Zeszyty Naukowe Uniwersytetu Zielonogórskiego. Seria Scripta Humana", t. 5 (2016); Kryminat. Okna na świat, „Zeszyty Naukowe Uniwersytetu Zielonogórskiego. Seria Scripta Humana”, t. 9 (2017); Literatura popularna, t. 3: Kryminat, red. E. Bartos, K. Niesporek, Katowice 2019. 
Joanna Chłosta-Zielonka zauważając, że stają się one szczególnym świadectwem ponowoczesnej rzeczywistości, wielką narracją o społeczeństwie:

Powieść kryminalna pisana jest współcześnie zamiast powieści społeczno-obyczajowej, nierzadko zamiast powieści środowiskowej, z zachowaniem jej podstawowych cech gatunkowych. Najważniejsza $z$ nich to konwencja realistyczna potrzebna do zilustrowania świata przedstawionego. Związane z nią są: faktograficzność, szczegółowy opis środowiska, czerpanie ze współczesnego życia społecznego i, co najważniejsze, narrator wszechwiedzący².

Inny z badaczy podkreśla, że literatura kryminalna, przekraczając własne ograniczenia związane $\mathrm{z}$ funkcjonowaniem $\mathrm{w}$ obiegu popularnym, zaczęła stawiać diagnozę rzeczywistości, poszukując odpowiedzi na pytania egzystencjalne, społeczne, epistemologiczne, moralne, przy tym niejednokrotnie stając się wyrazem potrzeby zrównoważenia nieprzewidywalności życia przez swą skonwencjonalizowaną formułę ${ }^{3}$. Współczesna powieść sensacyjna towarzyszy postmodernistycznym wizjom człowieka pogrążonego w chaosie, rozpadzie, nastawionego na konsumpcjonizm, odciętego od sfery wartości, pomijającego przeszłość i niepotrafiącego sprostać teraźniejszości. Z jednej strony mnożą się poszukiwania w obrębie nowych form tekstualności, próby eksperymentu literackiego, z drugiej zaś można zaobserwować różnorakie gry w obrębie synkretycznie traktowanych konwencji, czerpanie z szeroko pojętej przestrzeni tradycji, poszukiwanie kontekstów interpretujących tożsamość społeczno-kulturową ${ }^{4}$. W trend kontaminacji odmiennych form gatunkowych i stylów narracji wpisuje się mariaż powieści kryminalnej z dyskursem historycznym, realizowany w rozmaitych wariacjach cieszącego się niesłabnącą popularnością kryminału retro. Według Pawła Kaczyńskiego tym terminem określa się powieści sięgające wstecz do mniej więcej połowy XIX wieku, których akcja dzieje się w czasach od momentu pojawienia się nowoczesnych instytucji, metod i technik śledczych ${ }^{5}$. Kryminał retro został rozpropa-

\footnotetext{
2 J. Chłosta-Zielonka, Zamiast powieści obyczajowej. Cechy współczesnej polskiej powieści sensacyjnej, „Media - Kultura - Komunikacja Społeczna” 2013, nr 9, s. 91-92, [w:] Platforma Czasopism Uniwersytetu Warmińsko-Mazurskiego w Olsztynie, [źródło internetowe:] http:// uwm.edu.pl/mkks/wp-content/uploads/zamiast_powiesci_obyczajowej_cechy_wspolczesnej_ polskiej_powiesci_sensacyjnej.pdf, dostęp: 15.01.2020.

A. Mazurkiewicz, Tendencje rozwojowe wspótczesnej literatury kryminalnej, [w:] Śledztwo w sprawie gatunków. Literatura kryminalna, red. A. Gemra, Kraków 2014, s. 174.

4 O niejednorodności gatunkowej współczesnego kryminału zob. m.in.: V. Wróblewska, Tendencje rozwojowe polskiej literatury kryminalnej po 1989 roku, „Acta Universitatis Wratislaviensis. Literatura i Kultura Popularna”, 2011, t, XVII, s. 127-145.

5 P. Kaczyński, Kryminat historyczny - próba poetyki, [w:] Śledztwo w sprawie gatunków..., s. 192.
} 
gowany u nas m.in. za sprawą powieści rosyjskiego pisarza Borisa Akunina, a w literaturze polskiej zainicjowany przez Marka Krajewskiego najpierw serią o Wrocławiu lat przedwojennych i wojennych (rozpoczętą w 1999 roku Śmiercia w Breslau), a następnie o Lwowie (Gtowa Minotaura z 2008 roku i kolejne powieści). Jak pisze podążająca śladem literackich retrozbrodni Katarzyna Wajda:

Przepis na kryminał retro pozornie jest prosty: czas - przeszłość mniej lub bardziej odległa, najlepiej międzywojnie, miejsce - miasto (preferowane multikulturowe), bohater - wyrazisty, niepokorny, raczej á la Marlowe niż Poirot. I oczywiście interesująca zagadka, najlepiej mroczna, z większą lub mniejszą nutką dekadencji, podważająca mit o starych dobrych (czytaj: spokojnych) czasach albo, przeciwnie, budząca tęsknotę i zazdrość, że kiedyś, wszystko, łącznie ze zbrodnią, było lepsze ${ }^{6}$.

Sam termin retro - według autorki - początkowo funkcjonujący jako synonim międzywojnia, „świata podwójnie utraconego nie tylko przez naturalny upływ czasu, ale też zmiany historyczne"7, stopniowo zaczął ulegać przesunięciu, zarówno w stronę powojennej rzeczywistości (np. w lubelskim cyklu Marcina Wrońskiego o komisarzu Maciejewskim), jak i wstecz, ku schyłkowi XIX i początkom XX stulecia (np. Raport Badeni Krzysztofa Maćkowskiego przenosi czytelnika do Krakowa AD 1900, Sekret Kroke Małgorzaty i Michała Kuźmińskich proponuje wędrówkę po przedwojennym krakowskim Kazimierzu, a Krzysztof Beśka Trzeci brzeg Styksu lokuje w scenerii „ziemi obiecanej" dziewiętnastowiecznej Łodzi). Już dekadę temu notowano, że powieści, „których akcja rozgrywa się na przełomie wieków XIX i XX albo w okresie międzywojennym, tworzą w tej chwili rozległe zjawisko literackie, a kryminalna mapa Polski rozrasta się w zastraszającym wręcz tempie, tak jak i lista miast „opanowanych" przez zbrodnię".

Obraz ten byłby niepełny bez Lwowa, należącego do najczęściej wybieranych przestrzeni w gatunkach wykorzystujących stylizację retro we współczesnej literaturze zarówno polskiej, jak i ukraińskiej. Poza odnotowanym już cyklem Marka Krajewskiego o komisarzu policji Edwardzie Popielskim (Głowa Minotaura, Erynie, Liczby Charona) warto przywołać powieści Pawła Jaszczuka z dziennikarzem śledczym lwowskiego „Kuriera” Jakubem Sternem, który zajmuje się najbardziej drastycznymi zbrodniami notowanymi w kronice kryminalnej lat 30. (Foresta Umbra, Plan Sary, Marionetki, Aku-

\footnotetext{
$6 \quad$ K. Wajda, Śladem retrozbrodni, [w:] „Dwutygodnik.com”, [źródło internetowe:] https:// www.dwutygodnik.com/artykul/3820-sladem-retrozbrodni.html, dostęp: 15.01.2020.

Ibidem.

8 M. Kosmala, Kryminalne retroświaty, [w:] Przerabianie XIX wieku, red. E. Paczoska, B. Szleszyński, Warszawa 2011, s. 224.
} 
szer śmierci). Lwów (Lemberg, Leopolis) niezwykle często ożywa również w narracji ukraińskiej powieści nawiązującej do stylistyki retro, by wspomnieć o kryminałach Andrija Kokotiuchy o adwokacie Klimencie Koszowym (Adwokat z Lyczakowskiej, Widmo z Wałowej, Samochód z Piekarskiej) i Bohdana Kołomijczuka, autora szpiegowskiej serii o przygodach komisarza Adama Wistowicza (Ciemnica dusz, Niebo nad Wiedniem, Ekspres do Galicji, a także wydany niedawno w polskim przekładzie Hotel Wielkie Prusy, gdzie akcja przenosi się do Poznania), czy też w powieściach Anny Chomy, Oksany Dumańskiej, Jurija Wynnyczuka, Petra Jacenki, Władysława Iwczenki.

Do ciekawszych realizacji kryminalnego nurtu retro osadzonego w epoce fin de siècle'u należy włączyć krakowski cykl Maryli Szymiczkowej, który zyskał uznanie nie tylko wśród miłośników gatunku. Dotąd ukazały się cztery pozycje sygnowane marką Wydawnictwa Znak Literanova oraz piórem Jacka Dehnela i Piotra Tarczyńskiego: Tajemnica Domu Helclów (2015), Rozdarta zastona (2016), Seans w Domu Egipskim (2018) i Złoty róg (2020) ${ }^{10}$. W czerwcu 2019 roku fragmenty bestsellerowej trylogii o przygodach profesorowej Szczupaczyńskiej stały się kanwą spektaklu teatralnego Seans w Kamienicy Szolayskich, prezentowanego w scenograficznej oprawie wystawy „Rok 1900" Muzeum Narodowego w Krakowie ${ }^{11}$. Można przypuszczać, że kwestią czasu jest powstanie kolejnych tomów, tymczasem wiosną 2019 roku ukazała się anglojęzyczna wersja pierwszej części Mrs Mohr Goes Missing w przekładzie Antonii Lloyd-Jones, dzięki czemu Zofia Szczupaczyńska vel Turbotynska zyskuje szansę na międzynarodową karierę ${ }^{12}$. W czym zatem tkwi fenomen Szymiczkowej, wdowie po prenumeratorze „Przekroju”, królowej pischingera, niegdysiejszej gwiazdy Piwnicy pod Baranami i korektorce

\footnotetext{
9 Zob. M. Jaskot, J. Ganoshenko, Lwów jako konstrukt nostalgiczny polskiego i ukraińskiego kryminatu retro, [w:] 50 twarzy popkultury, red. K. Olkusz, Kraków 2017, s. 612-613, [w:] ResearchGate, [źródło internetowe] https://www.researchgate.net/publication/318672970 Lwow jako konstrukt nostalgiczny polskiego i ukrainskiego kryminalu retro, dostęp: 31.03.2020.

10 Jak czytamy na stronie wydawcy, książki ukazujące się pod szyldem Wydawnictwa Znak Literanova to zarówno proza z najwyższej półki, jak i książki inspirowane popkulturą w najlepszym wydaniu oraz idące pod prąd - eksperymentujące $\mathrm{z}$ formą i treścią, odważne, komentujące wydarzenia i trendy XXI wieku. Zob. [w:] Wydawnictwo Znak, [źródło internetowe:] https:// www.wydawnictwoznak.pl/wydawnictwo-znak-literanova, dostęp: 15.01.2020.

11 Scenariusz i reżyseria Maja Luxenberg, obsada: Natalia Kaja Chmielewska, Stanisław Linowski, Maja Luxenberg, Łukasz Szczepanowski. Premiera 9 czerwca 2019 roku w Kamienicy Szołayskich w Krakowie. Zob. Muzeum Narodowe w Krakowie, [źródło internetowe:] https:// mnk.pl/aktualnosci/seans-w-kamienicy-szolayskich, dostęp: 30.11.2019.

12 Wydanie, które wyszło nakładem londyńskiej oficyny Oneworld Publications, wsparł Instytut Książki w ramach Programu Translatorskiego CPOLAND. Warto wspomnieć, że Instytut dofinansował także kilka innych przekładów prozy Jacka Dehnela: Lala ukazała się po rosyjsku (w przekładzie Jurija Czajnikowa), ukraińsku (w przekładzie Bożeny Antoniak) i angielsku (w przekładzie Antonii Lloyd-Jones), a Matka Makryna i Krivoklat wyszły na Ukrainie (w przekładzie Andrija Bondara).
} 
w „Tygodniku Powszechnym” - cytując spreparowany biogram autorki powołanej do życia przez Dehnela i Tarczyńskiego? ${ }^{13}$.

Do sukcesu serii, wspomaganego zręcznymi chwytami marketingowymi, niewątpliwie przyczyniła się wyrazista kreacja detektywa-amatora, w którą wciela się stateczna mieszczka profesorowa Szczupaczyńska. Najtrafniejsza bodaj charakterystyka bohaterki pada na 139 stronie Tajemnicy Domu Helclów: „Niewiele było w Krakowie drzwi, łącznie z drzwiami aresztu, których Szczupaczyńska nie mogła otworzyć. A przynajmniej lekko uchylić"14. Codzienność Zofii koncentruje się wokół wspierania kariery męża, który dzięki jej ambicjom doszedł do stanowiska profesora nadzwyczajnego w katedrze anatomii Uniwersytetu Jagiellońskiego, udzielania się w akcjach społecznych oraz energicznego zawiadywania organizacją życia w kamienicy Sub Pavone przy ul. Św. Jana. Jako przykładna pani domu musi pamiętać o dyspozycjach dla kucharki, zakupie wina przeciwko cholerze, nadzorowaniu kolejnych służących i smażenia śliwkowych konfitur. Profesorowa, wywodząca się $\mathrm{z}$ aptekarskiej rodziny Glodtów z Przemyśla, „w codziennej walce o przemianę w idealną krakowiankę, której nikt nie ośmieli się wypomnieć prowincjonalnego pochodzenia" (TDH, 19), zdołała przejąć wszystkie zwyczaje tutejszego mieszczaństwa: zakupy robiła w Sukiennicach, w towary kolonialne zaopatrywała się w sklepie Antoniego Hawełki, suknie i kapelusze nabywała w magazynie mód Marii Praussowej, na sumę chodziła do kościoła Mariackiego, a z gazet czytywała tylko „Czas” (zob. TDH, 23). Czy zatem w poukładanym świecie szanowanej profesorowej może być miejsce na sensacyjną aferę? Więcej w niej swojskiej pani Dulskiej, czy jednak bliżej jej do panny Marple?

Równocześnie w codziennym życiu, w zawiadywaniu służbą i wymianie plotek, czuła się jak w zbyt ciasno zasznurowanym gorsecie. Niekiedy, ułożona na kanapie, kładła na podołku książkę z zaznaczoną wskazującym palcem stroną i myślała o tym, że w innych czasach mogłaby się lepiej odnaleźć; widziała siebie

\footnotetext{
13 Autorzy posługują się pseudonimem dystansując się wobec eksperymentu o charakterze komercyjnym, który znajduje się na uboczu ich działalności literackiej. Podobną rozdzielność zachowywał Maciej Słomczyński, publikujący powieści sensacyjne i kryminalne jako Joe Alex i Kazimierz Kwaśniewski. Nie jest też zjawiskiem odosobnionym wspólne pisanie kryminałów, w ostatnich latach autorskie duety stworzyli m.in. Marek Krajewski i Mariusz Czubaj, Katarzyna Gacek i Agnieszka Szczepańska, Marta Mizuro i Robert Ostaszewski, Małgorzata i Michał Kuźmińscy.

14 Dalsze cytowania powieści M. Szymiczkowej Tajemnica Domu Helclów (Kraków 2015) będą opatrzone skrótem TDH i numerem strony. Analogicznie skrót RZ odnosić się będzie do tomu Rozdarta zastona (Kraków 2016), a SDE - do Seansu w Domu Egipskim (Kraków 2018). Nie będzie przywoływany ostatni tom serii, Zloty róg, którego premiera odbyła się w listopadzie 2020 roku, już po złożeniu do druku niniejszego artykułu. Do kontynuacji przygód profesorowej Szczupaczyńskiej, tym razem osadzonych w kontekście słynnego wesela w Bronowicach, powrócimy przy innej okazji.
} 
jako Kleopatrę, Zenobię, może Grażynę, może angielską Elżbietę, może Joannę d'Arc wreszcie - w każdym razie jako kobietę władczą, wiodącą hufce w pole, odzianą to $\mathrm{w}$ zbroicę przepyszną, jak prosto $\mathrm{z}$ obrazu Matejki, to w sute suknie z płócien Gierymskiego albo antyczne chitony Siemiradzkiego... tymczasem musiała kontentować się wydawaniem poleceń Franciszce, obmyślaniem posiłków na najbliższy tydzień i pilnowaniem, żeby pulardę na czas wyjęto z pieca.

$(\mathrm{TDH}, 39)$

Kiedy więc Szczupaczyńska przypadkiem dowiaduje się, że w Domu Helclów ${ }^{15} \mathrm{w}$ tajemniczych okolicznościach zniknęła jedna z pensjonariuszek, bezzwłocznie przystępuje do działania. Starania o patronat i fanty na loterię dobroczynną dla dzieci skrofulicznych stają się pretekstem do podjęcia dyskretnego śledztwa, które prowadzi do odnalezienia ciała zaginionej staruszki, a następnie podważenia świadectwa zgonu, odkrycia motywu dwóch popełnionych zbrodni i mordercy. Półtora roku później w Rozdartej zasłonie profesorostwo Szczupaczyńscy muszą zmierzyć się z tragiczną śmiercią swej młodej służącej Karolci, która - jak się okazuje dzięki wnikliwości amatorskiej śledczej - padła ofiarą międzynarodowego handlu żywym towarem i policyjnej korupcji. W trzeciej powieści Seans w Domu Egipskim zbrodnia dzieje się właściwie na oczach profesorowej, uczestniczącej w wieczorze spirytystycznym, podczas którego dochodzi do nagłego zgonu gospodarza. Tym samym Szczupaczyńska nie tylko jest w centrum wydarzeń, ale też - mając już spore doświadczenie i pewną renomę w wydziale śledczym - zaczyna sprawnie zawiadywać dochodzeniem. Niejednokrotnie zaskakuje przy tym znajomością prawnych procedur i erudycją w zakresie prężnie rozwijających się wówczas nauk kryminalistycznych. Nie trzeba dodawać, że wymaga to dyplomatycznej strategii w świecie, w którym kobiety dopiero zaczynają sobie torować drogę na uniwersytety.

Detektyw w powieści kryminalnej jest kluczowym ogniwem fabuły często łączącym kolejne tomy książkowe, co sprawia, że mimo odrębnej intrygi występują między nimi celowe nawiązania, a portret postaci może być wzbogacany o nowe rysy. Klasycznym przykładem są Herkules Poirot i Jane Marple z powieści Agathy Christie, postaci o wyraźnie komicznych czy satyrycznych predylekcjach, mocno uwypuklonych również w kreacji Szczupaczyńskiej. Profesorowa - przynajmniej do pewnego momentu - całą swą energię ukierunkowując na mężowską karierę, zdecydowanie preferuje uświęcony tradycją porządek społeczny. ,Tak naprawdę Zofia Szczupaczyńska nie kwestio-

15 Dom Ubogich im. Helclów w Krakowie powstał dzięki fundacji Ludwika i Anny Helclów w 1890 roku (obecnie Dom Pomocy Społecznej im. L. i A. Helclów). Zgodnie z wolą fundatorki bezpośredni zarząd nad zakładem i opiekę nad pacjentami miały sprawować Siostry Miłosierdzia. 
nowała opinii, że niektóre sprawy na tym padole przeznaczone są dla jednej płci, a drugie - innej, taki już jest porządek rzeczy, a mieszanie ich jest niepotrzebne, a może i szkodliwe" (TDH, 88). Wchodząc w swą nowo odkrytą rolę, „,wolała o tym myśleć jako o «badaniu», «szperaniu», «szukaniu prawdy» czy nawet «niewinnych kobiecych przeszpiegach»" (TDH, 89). W każdej kolejnej historii „tropicielka z powołania” coraz mocniej angażuje się w sprawy śledztwa, penetruje mroczne zakamarki znosząc „najbardziej nieobyczajne historie z półświatka, jeśli doprowadzi ją to do rozwiązania zagadki" (RZ, 229), zaś „po paru rozwiązanych zagadkach stała się uzależniona od zbrodni jak morfinistka od swojej ukochanej trucizny" (SDE, 79). Na co dzień wyznawczyni etykiety, w śledczym ferworze zręcznie omija obyczajowe konwenanse, by inicjować salonową konwersację o rodzajach i działaniu trucizn, wizytować modne artystyczne kawiarnie i podrzędne hotele, redakcje socjalistycznych burzycieli czy siedziby literatów-dekadentów. Nie bez powodu w Rozdartej zasłonie Szczupaczyńska z zajęciem podczytuje drukowaną w „Czasie” bestsellerową nowelkę Roberta Louisa Stevensona Dziwny wypadek Dra Jekyll i Mra Hyde $e^{16}$, a sama często czuje się niczym Helena Modrzejewska na scenie.

Poczuła ukłucie winy, że swoje drugie życie prowadzi nie tylko obok małżeńskiego stadła, ale wręcz zamiast niego. To, co powinno jej, jako kobiecie, wystarczać - dobry mąż, udany dom, działalność na niwie dobroczynnej, opieka duchowa Kościoła - zeszło zdecydowanie na dalszy plan. Ekscytacja z powodu awanturniczych poszukiwań mordercy dalece przewyższała radość statecznego dbania o ognisko domowe; wertowanie czasopism w bibliotece cieszyło ją o wiele bardziej niż studiowanie książeczki do nabożeństwa, a zbieranie datków na renowację katedry nie mogło równać się z gromadzeniem tropów i z próbami ułożenia z nich mozaiki, która wyjawiłaby sekret zabójstwa Karolci.

Balansowanie profesorowej na granicy różnych światów nie powiodłoby się bez pomocy zaufanej służącej, nieocenionej zarówno w nawiązywaniu kontaktów w ,pewnych sferach”, jak i utrzymaniu tajemnicy przed mężem, bowiem „Ignacy nie mógł nabrać podejrzeń, że jego żona, zamiast zajmować się sprawami właściwymi jej płci, pozycji i regułom uczciwego małżeństwa, rozbija się po budynkach użyteczności publicznej w poszukiwaniu jakiegoś zbója-dusiciela” (TDH, 119). I dalej: ,[...] po prostu obie zasmakowały w tym samym: szperaniu w ludzkich losach i udowadnianiu, że rzeczywistość wygląda zgoła inaczej, niż to się niektórym wydawało" (TDH, 247). W każdym kolejnym śledztwie rezolutna kucharka Franciszka otrzymuje coraz poważniejsze zadania, a jako medium podczas seansu w Domu Egipskim

16 Nowela szkockiego pisarza po raz pierwszy w oryginale opublikowana w 1886 roku, drukowana w odcinkach na łamach krakowskiego „Czasu” od 17 kwietnia 1895 roku. 
pełni kluczową rolę w rozegraniu finalnej sceny zdemaskowania zbrodniarza. O postępach śledztwa i rozwiązaniu kryminalnej zagadki przez policję Szczupaczyńscy zawsze dowiadują się z kronik ulubionej gazety, czyli „Czasu”, czego Zofia - doskonale wszak obeznana z kulisami śledztwa - bynajmniej nie zamierza kwestionować, mimo że wraz $\mathrm{z}$ nabywaniem nowych doświadczeń, jak i ze zmieniającą się na jej oczach rzeczywistością, stopniowo zaczyna rewidować swój stosunek do wielu spraw.

Od jakiegoś czasu dojrzewała jednak w niej potrzeba znalezienia powiernika. Miała u boku, oczywiście, Franciszkę, nieocenioną wprawdzie w sprawach wymagających kobiecego sprytu czy kontaktów z... hm... ze swoją klasą, ale Zofii brakowało kogoś, kto należycie ją doceni... [...] chciała, by ktoś poznał jej sekret, by w statecznej doktorowej Jekyll docenił pannę Hyde, nieustraszoną tropicielkę zbrodni.

$(\mathrm{RZ}, 142)$

Kryminały Szymiczkowej perfekcyjnie realizują klasyczny schemat fabularny powieści detektywistycznej z detektywem-amatorem w roli głównej, od zabójstwa do zidentyfikowania sprawcy i wyjaśnienia krok po kroku wszystkich okoliczności wydarzeń. Ostatnie ogniwa śledztwa wraz z zawiłościami motywacji zbrodni, rozgrywające się poza świadomością czytelnika, zostają ujawnione w finalnej scenie kulminacyjnej komponowanej w sposób typowy dla powieści Agathy Christie, kiedy dowiadujemy się, kto i dlaczego zabił. Całej serii o przygodach Szczupaczyńskiej trudno odmówić inwencji i precyzji w konstruowaniu intrygi kryminalnej - trzeba przyznać - za każdym razem utrzymanej w pełni dramaturgicznego napięcia, z mylnymi tropami i zwrotami akcji. W Rozdartej zastonie dodatkowo została zastosowana metoda konfrontacyjnego prowadzenia fabuły, w której wyspecjalizowany policjant podsuwa fałszywe rozwiązania zacierając ślady zbrodni, a dociekliwy detektyw-amator drąży sprawę aż do momentu ujawnienia pełnych okoliczności wydarzeń.

W przypadku kryminału retro najistotniejsza obok samej zagadki morderstwa jest rekonstrukcja obrazu przeszłości, dążenie do oddania atmosfery czasu i miejsca. Tym, co wyróżnia pióro Szymiczkowej, jest drobiazgowe, a do tego nie pozbawione satyrycznego nerwu odtworzenie realiów oraz ducha dziewiętnastowiecznego Krakowa i jego socjety, z całą ówczesną obyczajowością, galicyjskimi stosunkami społeczno-ekonomicznymi, właściwościami języka, kulinariami, modą ${ }^{17}$. Autorzy - zgodnie z poetyką kryminału retro -

17 Jako przykład niech posłuży wyimek Rozdartej zasłony: „Co jak co, ale nakrycia głowy potrafiły budzić w Krakowie wielkie emocje. Pamiętano, że kiedy pani Wojciechowa Kossakowa przeszła się kiedyś po linii AB w sprowadzonym z Paryża kapeluszu o dość oryginalnej formie, parę dni później „Czas” zagrzmiał, że istny horror, kapelusz fioletowy z przodu, zielony z tyłu, paryskie ekstrawagancje i tak dalej. Plotka głosiła, że po tym artykule żona malarza przez trzy dni nie odważyła się wyjść z domu, choćby na spacer wzdłuż Rudawy. Prawda to czy 
w celu nadania faktograficznego i realistycznego prawdopodobieństwa dużą wagę przywiązują do starannej kwerendy źródłowej, przeszukiwania gazet, czasopism, pamiętników, listów etc., wyłuskując z nich atrakcyjne wydarzenia, które stają się pożywką bądź tłem dla fikcyjnej intrygi kryminalnej. Jak objaśniają, taka metoda pracy wynika z wyboru określonego podgatunku kryminału, wywodzącego się z rodowodu Agathy Christie. „Bo to nie tyle jest historia pewnej zbrodni - choć oczywiście typowy czytelnik kryminałów może mieć $\mathrm{z}$ lektury frajdę - ale również portret społeczeństwa, miasta, epoki, z nawiązaniami do konkretnych osób historycznych, $\mathrm{z}$ wycieczkami do różnych nieistniejących albo zupełnie zmienionych miejsc"18.

Kryminał retro bardzo skrupulatnie traktuje toponimię, szczegółowo rejestruje trasy przemieszczania się bohaterów, często stając się środkiem nawigacji w historycznej przestrzeni miasta także poza granicami utworu literackiego. W świecie Szymiczkowej mamy zderzenie tradycjonalistycznych mieszczańskich salonów, będących naturalnym środowiskiem głównej bohaterki, z rzeczywistością, która dla statecznej matrony wydawać by się mogła kompletną terra incognita. Szczupaczyńska z jednej strony chadza utartymi szlakami Rynku i Plant (wszystko, co wykraczało poza linię „Plantacji”, wydawało się ówczesnym krakowianom odległe od centrum miasta), z drugiej zaś odkrywa wielokulturowy świat istniejący poza ich obrębem - rzecz jasna z zachowaniem zasad dyskrecji, a nieraz i w kamuflującym postać przebraniu - wizytując trzeciorzędne hotele, wyprawiając się na żydowski Kazimierz czy do podkrakowskich wsi i miasteczek. Każde wyjście, choćby to były zwykłe sprawunki, zawsze jest ulokowane w dokładnej topografii ulic i uliczek, z drobiazgowym oddaniem detali architektonicznych mijanych kamienic i budynków użyteczności publicznej, klimatu tłocznych bazarów czy treści afiszów reklamujących cyrk Sidolego, do którego ma słabość kucharka Szczupaczyńskich. Znużeniu czytelnika podążającego śladami ruchliwej profesorowej przeciwdziała forma wszechwiedzącej narracji, łącząca precyzję rzeczowego opisu spotykanych osób i miejsc z subiektywnymi reakcjami bohaterów i satyrycznymi komentarzami na temat mijanych obiektów.

Szły jak zawsze: Świętego Jana, potem Tomasza, co jakiś czas popatrując z niechęcią na tę samą chmurę, wzbierającą, puchnącą, kotłującą się ponad Piaskiem.

\footnotetext{
nie, faktem było, że nigdy już nie pokazała się w tym kapeluszu publicznie. Z drugiej strony - pomyślała Szczupaczyńska - stara hrabina Potocka mogła się pojawić w teatrze z całym ogrodem tropikalnym na głowie, w którym brakowało jedynie papugi, a nie spotkało ją za to słowo krytyki. Cóż, hrabiny i księżne zawsze podlegały innym prawom niż reszta śmiertelniczek, taki już był ustalony porządek rzeczy" (RZ, 166).

18 Eksperyment, rozmowa Agnieszki Sowińskiej z Jackiem Dehnelem i Piotrem Tarczyńskim, [w:] „Dcutygodnik.com”, [źródło internetowe] https://www.dwutygodnik.com/artykul/6039-eksperyment.html, dostęp: 15.01.2020.
} 
[...] Dochodziły już do wylotu Świętego Tomasza, więc Franciszka, która szła nieco z tyłu, z koszem przewieszonym przez ramię, wiedziała, co zaraz nastąpi: na wysokości kamienicy Sędziwoja kokarda na kapeluszu nagle drgnęła i skręciła w prawo, a za nią reszta kapelusza i głowa profesorowej. Przyszedł czas na jęknięcie, bo stąd już było widać „tę zbrodnię”, „tę ohydną szopę, godną stacyjki w mieście garnizonowym", czyli ogromną konstrukcję krytych schodów ewakuacyjnych, dobudowaną parę lat temu do gmachu miejskiej sceny po pożarze stołecznego Ringtheatru.

- Rozumiem, że tam spłonęło blisko czterysta osób - mawiała profesorowa Szczupaczyńska - ale czy to powód, żeby Wiedeń mścił się na Krakowie tym szkaradzieństwem? Na szczęście nowy teatr już lada moment ${ }^{19}$.

(TDH, 12-13)

Było jej spieszno. Po prawej przemknęła szeroka fasada Bernardynów, po lewej - Misjonarzy, wreszcie dawny kościół Świętej Jadwigi, wiek temu przebudowany przez Austriaków na jakieś urzędy, a potem pocztę; kiedy parę lat temu wzniesiono nowy gmach pocztowy na Wielopolu - ,godny Lwowa i Wiednia”, jak mawiano z pewną przesadą - na Stradom wprowadziła się jedna z niezliczonych instytucji wojskowych, dowództwo garnizonu, i teraz przez okna migały postaci siedzących za biurkami armijnych gryzipiórków.

W tym kontekście warto zwrócić uwagę na uchwycony u Szymiczkowej obraz Lwowa, który w zestawieniu z nieco sennym, przywiązanym do tradycji Krakowem jawi się jako tętniąca życiem nowoczesna metropolia, korzystająca z najnowszych osiągnięć techniki, wnosząca powiew wielkiego świata, w którym toczą się procesy sądowe o międzynarodowym zasięgu (widać to np. w Rozdartej zastonie, kiedy lwowskie gazety dostarczają kluczowych informacji dotyczących prowadzonego śledztwa). Lwów, w krakowskim cyklu stanowiący dość odległe, ale istotne tło, pojawia się w centrum wielu tekstów kultury wykorzystujących stylistykę retro, dla których jest on atrakcyjny ze względu na „oryginalną historię, i wysoki poziom stereotypowości w jego odbiorze, i bogatą zewnętrzną (środowiskową) stronę [...], specyfikę schematów komunikacyjnych i tras turystycznych”. „Lwów z początku wieku jest tak samo egzotyczny dla tożsamości współczesnego Ukraińca, jak i dla samoidentyfikacji kulturowej współczesnego Polaka" - stwierdzają Maciej Jaskot

\footnotetext{
19 Obiektem komentarza Szczupaczyńskiej jest teatr przy placu Szczepańskim (obecny Narodowy Stary Teatr im. H. Modrzejewskiej). Powstały po przebudowaniu budynków mieszkalnych, mimo remontów nie spełniał wymogów technicznych i przeciwpożarowych. Po tragedii, jaka wydarzyła się w wiedeńskim Ringtheater w 1881 roku podczas galowego przedstawienia, do budynku krakowskiego teatru dobudowano prowizoryczną drewnianą klatkę schodową. Jesienią 1886 roku Rada Miasta zdecydowała o budowie nowego teatru na placu Św. Ducha, którego inauguracja odbyła się 21 października 1893 roku.
} 
i Jurii Ganoshenko, wskazując na obecność nostalgii jako elementu strategii pisarskiej i rzeczywistości tekstowej we współczesnym polskim i ukraińskim kryminale ${ }^{20}$. Charakterystyczną metodą kreowania nostalgicznego obrazu miasta jest zogniskowanie uwagi na mikroobrazowości, rejestrowanie codziennego otoczenia człowieka ze szczegółami niemającymi większego znaczenia dla rozwoju głównego wątku. Tworzony w narracji kryminału retro wizerunek Lwowa utrwala silnie zakorzenione w pamięci kulturowej wyobrażenie jako ośrodka postępu, niezwykle dynamicznego miasta, gdzie już ,powstały i funkcjonują wszystkie formy kultury popularnej: środki masowego przekazu, kino, marki w modzie, wzornictwie, jedzeniu i napojach, restauracjach i hotelach"21. W kryminałach Szymiczkowej ogólne postrzeganie miasta dopełniają epizodyczne rysy sytuacyjne, Zofia na przykład zachowała

[...] jak najgorsze wspomnienia z podróży elektrycznym tramwajem podczas lwowskiej Wystawy Krajowej, którą odwiedzili z mężem minionego roku. Choć nieżyczliwi mogliby powiedzieć, że przyczyną tego była zwykła zazdrość wobec większej, zamożniejszej, a przede wszystkim o wiele znaczniejszej stolicy Królestwa Galicji i Lodomerii, profesorowa swoją niechęć wobec tramwajów elektrycznych tłumaczyła względami czysto praktycznymi. [...] Ku jej zadowoleniu tramwaje krakowskie wciąż przemieszczały się w tempie nieodbiegającym zbytnio od prędkości, jakie rozwijał kursujący tą trasą wcześniej konny omnibus, a które ona sama określała mianem «rozsądnych».

(RZ, 53).

Równie dokładny i obfitujący w szczegóły natury historycznej jest czas wydarzeń, mocujący fikcję literacką w konkretnych realiach. Swoisty reżim od początku narzuca wprowadzanie dat dziennych, na ogół nieprzypadkowo wybieranych z kalendarza. I tak w Tajemnicy Domu Helclów główna część akcji rozpoczyna się 14 października 1893, a kończy pierwszego dnia AD 1894. Rozdarta zasłona obejmuje okres od Wielkanocy 1895 do połowy września 1896 roku. Natomiast Seans w Domu Egipskim zamyka się w ciągu mniej więcej tygodnia, pomiędzy ostatnimi dniami grudnia 1898 a świętem Trzech Króli roku 1899. Przygody fikcyjnych postaci osadzone są na tle autentycznych zdarzeń, zarówno spektakularnych, odbijających się rozległym echem nie tylko w Krakowie, jakimi są inauguracja nowo wybudowanego teatru, pogrzeb Jana Matejki, przyjazd Stanisława Przybyszewskiego, występy Heleny Modrzejewskiej czy Ignacego Jana Paderewskiego, jak i codziennych kronikarskich wzmianek. Bohaterom towarzyszą aktualne sprawy lokalnej i światowej polityki, wydarzenia kulturalne, jubileusze, drobne przestępstwa i wypadki, anomalie pogodowe. W dialogach i partiach narracyjnych roi się

20 M. Jaskot, J. Ganoshenko, op. cit., s. 612, 615.

21 Ibidem, s. 617-618. 
od cytatów z ówczesnej galicyjskiej prasy, głównie z „Czasu” - powszedniej lektury w domu Szczupaczyńskich, która jest nie tylko bezcennym źródłem informacji, ale bardzo często staje się pretekstem codziennych salonowych konwersacji i dyskusji. Bieżących nowinek okazjonalnie dostarczają też inne prasowe tytuły - „Nowa Reforma”, „Gazeta Lwowska”, „Kurier Lwowski”, „Gazeta Narodowa”, „Naprzód” czy „Gazeta Robotnicza”.

Kolejnym powieściowym chwytem jest bogata galeria postaci historycznych, z reguły przywoływanych pośrednio dla nadania autentycznego kolorytu, jak Matejko protestujący przeciwko lokalizacji gmachu teatru na placu Św. Ducha, brat Albert „,co tworzył, a potem poszedł na Kazimierz, na Piekarską, do ogrzewalni miejskiej” (SDE, 228), „ten pacykarz” Wyspiański, protegowany doktorowej Pareńskiej, wprowadzający estetyczną rewolucję w krakowskich kościołach i salonach, Juliusz Kossak dożywający swych ostatnich dni w willi przy placu Latarnia czy umierający krakowski okulista profesor Lucjan Rydel, którego syn „niby prawo ukończył, ale tylko mu jakieś sztuki i wiersze w głowie, biednemu Rydlowi grozi, że syn tak wybitnego lekarza zostanie jakimś... żurnalistą!" (RZ, 91). Podobne przykłady można by mnożyć. Niekiedy pisarska wyobraźnia posuwa się dalej, tworząc epizodyczne sytuacje z udziałem sędziwego dyrektora Biblioteki Jagiellońskiej, Karola Estreichera, pomagającego Szczupaczyńskiej w dotarciu do poszukiwanych informacji, mistrza murarskiego Michała Ezenkiera i jego zespołu kolędniczego pojawiającego się u profesorostwa z doroczną tradycyjną szopką, czy Dagny Juel sportretowanej podczas wizyty Zofii u Przybyszewskich. Niezwykle barwną figurą występującą we wszystkich odsłonach przygód profesorowej jest postać zdolnego asystenta Szczupaczyńskiego, „,chudego, lekko przygarbionego młodzieńca z czarną czupryną, Tadeusza Kamila Marcjana Żeleńskiego, studenta medycyny” (RZ, 176), który „miast uczyć się do egzaminów, spędzał czas na całonocnych, a czasem i całodziennych hulankach w towarzystwie dekadentów" (SDE, 154). Tadeuszek (wzorowany na Boyu-Żeleńskim) z racji swego pochodzenia wnosi aurę arystokratycznych salonów, do których usilnie aspiruje Szczupaczyńska, z każdym kolejnym śledztwem doceniająca zarazem użyteczność jego obycia w rejonach półświatka. Natomiast w trzecim tomie do akcji wkracza sam Przybyszewski, nie tylko w roli dekadenta drażniącego filisterską socjetę, ale też świadka zbrodni w Domu Egipskim, przez co znajduje się w ścisłym kręgu podejrzanych. Otoczony specyficzną dlań aurą skandalu i plotek, do tego „mówi sobą” posługując się cytatami z własnych dzieł, z Dzieci szatana, Confiteor czy Moich współczesnych.

Fundamentem współczesnej kultury popularnej jest kreowanie klisz i repetycji łatwych do rozpoznania przez odbiorcę. Jak zaznaczał Umberto Eco, ,[...] powieść popularna nie wymyśla oryginalnych sytuacji narracyjnych, lecz uprawia kombinatorykę toposów już uznanych, przyjętych, lubianych przez publiczność. [...] Przyjemność płynąca z narracji [...] płynie z powtarza- 
nia tego, co już znane: powtarzania cyklicznego zarówno w ramach jednego dzieła literackiego, jak i całej serii dzieł, w szeregu odwołań odsyłających od powieści do powieści" 22 . Charakterystyczną właściwością cyklu Szymiczkowej są całe partie tekstu będące ukrytymi wyimkami z przeróżnych źródeł - częściowo wskazywanych w odautorskim posłowiu ${ }^{23}$ - od rozpraw naukowych i popularnonaukowych, przez utwory literackie, aż po poradniki, książki kucharskie, wreszcie obficie cytowaną codzienną prasę. Na tym różnorodnym materiale opierają się relacje dotyczące ówczesnych zjawisk społecznych, ekonomicznych i kulturalnych, opisy wyposażenia wnętrz, elementów garderoby, modnych kosmetyków czy galicyjskich specjałów. Utwory te stanowią zarazem pastiszową pożywkę dla toczących się na kartach powieści dyskusji wokół kwestii, które angażowały Kraków końca XIX stulecia. Spróbujmy to uchwycić na przykładzie chętnie stosowanego przez Szymiczkową parafrazowania innego tekstu:

- „Życie”, powiedzieć muszę [...] z tygodnia na tydzień coraz ciekawsze. Nie myślał pan, panie Stanisławie, napisać większej jakiejś rzeczy o Ibsenie?

- Ibsen wciąż u nas za mało znany - przytaknął młodzieniec - za mało...

Przybyszewski wzruszył tylko ramionami, za to odezwała się Pszornowa, która bardzo chwaliła Trapszówną za rolę w Dzikiej kaczce.

- Parę już miesięcy minęło - zakończyła - bo widzieliśmy ją bodaj w kwietniu, ale po wyjściu pomyślałam, że każde kolejne pytanie katechizmu powinno brzmieć: „Po co żyjemy na tym świecie nazajutrz po przedstawieniu Dzikiej kacz$k i$, jeśli nie mamy nadziei powtórzenia?"

Obóz bohemy bardzo był tym żartem z katechizmu ubawiony, Zofia ani trochę.

- Ach, w kwietniu! A to przecież był benefis! - ożywiła się Iwańcowa. - Mieliśmy iść, bo zawsze sobie przyrzekałam być na benefisie naszej Teci kochanej, ale jak na złość dzień wcześniej poszliśmy z Damazym, tylko zresztą dla celu, bo dochód był na Towarzystwo Dobroczynności, na jakąś bezbarwną niemiecką wodziankę, nudną, choć nie ordynarną przynajmniej. A że Damazy nie chce, żebyśmy dzień po dniu chodzili do teatru, a już zwłaszcza na takie pesymizmem przepojone sztuki, to Teci w tym nie widziałam.

(SDE, 45-46)

Zestawmy teraz ten fragment $\mathrm{z}$ oryginałem pamiętnikarskich Wrażeń $i$ wspomnień młodej teatromanki, oddając głos ich autorce Elżbiecie Kietlińskiej, która pod datą 5 kwietnia 1898 roku zanotowała:

22 U. Eco, Superman w literaturze masowej. Powieść popularna między retoryka a ideologia, przeł. J. Ugniewska, wyd. 2, Kraków 2008, s. 100-101.

${ }_{23}$ „Czytelnik powinien mieć wrażenie, że oprócz rozrywki uzyskał też porcję certyfikowanej wiedzy" - komentuje Paweł Kaczyński. Posłowia z odniesieniami do źródeł stanowią element konwencji współczesnej twórczości kryminalnej, służący - jak zauważa Mariusz Czubaj „uwiarygodnieniu opisywanego świata i kompetencji autorskich”. M. Czubaj, op. cit., s. 184; P. Kaczyński, op. cit., s. 207. 
Znowu jestem zła. Hrabina Oczko, o której mówiono, że jest mądrzejsza od swego tytułu - to prawdziwa niemiecka wodzianka bezbarwna, tyle że nie ordynarna. Tylko starannej grze i wystawie, a zwłaszcza urodzie bohaterki (Siemaszkowa), zawdzięcza, że nie była nudna. Poszłam dla celu - przedstawienie było na dochód Tow. Dobroczynności - a tu dziś benefis Trapszówny w Dzikiej kaczce Ibsena. Choć to podobno za mądre dla przeciętnej publiczności, tak chciałam iść, bo sobie zawsze przyrzekałam być na benefisie naszej kochanej Teci. Jak ona w tym musi grać... Ale Mama nie chce, byśmy dzień po dniu do teatru chodziły i żebym ja chodziła na takie pesymizmem przepojone sztuki ${ }^{24}$.

A nieco dalej, wpis datowany 7 maja rozpoczyna się zdaniem:

„Po co żyjemy na tym świecie nazajutrz po przedstawieniu Lohengrina, jeśli nie mamy nadziei powtórzenia?" - powinno brzmieć pytanie katechizmu ${ }^{25}$.

Pozostając w kręgu literackich inspiracji warto zwrócić uwagę na pastiszowe retro-stylizacje języka dzieł autorów z epoki, jak też obecność licznych, mniej lub bardziej zakamuflowanych cytatów. I tak nostalgiczny obraz starego Krakowa pozostaje w klimacie nowelistycznych Typów i obrazków krakowskich Michała Bałuckiego czy wspomnieniowego opisu Karola Estreichera (Nie od razu Kraków zbudowano). Powiew moderny, wprowadzanej na salony w dysputach na temat nowej sztuki czy anegdotach o krakowskich dekadentach, wypływa z utworów Tadeusza Boya-Żeleńskiego, Stanisława Przybyszewskiego, Jana Augusta Kisielewskiego. Niejednokrotnie pobrzmiewa styl znany z korespondencji i młodopolskich wspomnień Gabrieli Zapolskiej, Lucyny Kotarbińskiej czy przywołanej wcześniej Elżbiety Kietlińskiej. Warto nadmienić, że jest to zarazem język epoki pośrednio recypowany za sprawą nieco dziś zapomnianego krakowskiego serialu Andrzeja Wajdy i Edwarda Kłosińskiego Z biegiem lat, z biegiem dni... ${ }^{26}$.

„Wierni czytelnicy współczesnych kryminałów coraz chętniej przyznają, że wątek związany z prowadzonym w powieściach śledztwem niekoniecznie stanowi dla nich istotę czytelniczej przyjemności. [...] równie ważne stają się inne, dotychczas stanowiące jedynie tło, elementy kryminalnego świata przedstawionego" 27 . Prowadzi to do poszukiwania przez ich twórców nowych

\footnotetext{
24 E. Kietlińska, Wrażenia i wspomnienia młodej teatromanki, wstęp i oprac. J. Michalik, Kraków 2012, s. 97.

25 Ibidem, s. 98.

26 Pierwowzorem serialu był siedmiogodzinny spektakl Z biegiem lat, z biegiem dni..., zrealizowany na podstawie utworów pisarzy młodopolskich i międzywojennych według scenariusza Joanny Olczak-Ronikier, który Andrzej Wajda wystawił na deskach Starego Teatru w Krakowie w 1978 roku.

27 M. Steckiewicz, Czas przeszly dokonany? Obraz międzywojnia w kryminatach retro, [w:] Śledztwo w sprawie gatunków..., s. 247.
} 
rozwiązań artystycznych, które rozsadzają tradycyjną konwencję powieści kryminalnej ${ }^{28}$. Od kryminału, a szerzej - od literatury popularnej, coraz częściej oczekuje się nie tylko silnych emocji i umysłowej łamigłówki, ale też zaspokojenia wyższych czytelniczych potrzeb, intelektualnej pożywki, refleksji o otaczającej rzeczywistości. Popkultura obecnie z dużą łatwością absorbuje artefakty kultury elitarnej, włączając je do codzienności, proponując swobodne mieszanie, przenikanie się gatunków. Kryminał retro może dostarczyć czytelniczej satysfakcji na różnych poziomach, a rozszyfrowywanie przemycanych $\mathrm{w}$ rozmaitych kontekstach tropów źródłowych, wymagające kompetencji kulturowych i erudycji literackiej, bywa nie mniej zajmujące niż śledzenie samej intrygi kryminalnej. Oczywiście im szersze horyzonty kulturowe i oczytanie odbiorcy, tym większa wrażliwość na ukryte w wielowarstwowym tekście niuanse i zabawy konwencją gatunkową. Drugim potencjalnym adresatem kryminału retro jest mniej wyrobiony czytelnik zanurzony w przestrzeni literatury popularnej, który nie będzie podążał meandrami intertekstualnych odniesień, ale poprzez obcowanie $\mathrm{z}$ historią wplecioną w kanwę sensacyjnej fabuły poszerzy swą wiedzę, nasiąkając klimatem modernistycznej kultury. Książkowy cykl Maryli Szymiczkowej wpisuje się w koniunkturę niesłabnącego popytu na powieść kryminalną osadzoną w dawnej przeszłości, a równocześnie gra z popkulturową konwencją, obficie czerpie z lamusa tekstów rozmaitej proweniencji rozpiętych między kulturą wysoką a popularną, wskrzeszając malowniczy obraz Galicji i młodopolskiego Krakowa, jego osobowości i osobliwości, wreszcie, last but not least, w lekkiej, anegdotycznej formie narracji odrabiając niejedną historyczno-kulturową lekcję. Jak twierdzą autorzy: „Taki chyba jest głębszy sens pisania kryminałów retro: pokazanie, że przeszłość wyglądała trochę inaczej, niż się uczymy w podręcznikach szkolnych"29.

\footnotetext{
28 Niczym w opowiadaniu Olgi Tokarczuk, w którym namiętna czytelniczka kryminałów musi się zmierzyć ze złamaniem kardynalnej zasady gatunku, czyli brakiem faktycznego mordercy (w rezultacie bohaterka sama wkracza do rzeczywistości książkowego świata, by nadać akcji właściwy bieg). „Spróbowała kryminałów podszytych literaturą, zaopatrzonych w drugie dno, nie zawsze jasne; otarła się o kryminały dziwaczne jak jakieś transgeniczne rośliny, posmakowała kryminałów-puzzli, kryminałów-poematów; do naga rozbierała kryminały-matrioszki, gdzie każdy kolejny rozdział wydobywał jeszcze jakieś inne znaczenia, inne historie pozornie nie związane z akcją; brnęła przez kryminały-traktaty-o, pełne erudycyjnych odniesień, które powinna była rozumieć, ale nie rozumiała; zmagała się z tymi, które udawały, że nie są kryminałami, lecz rozprawami o poznaniu czy moralności”. O. Tokarczuk, Otwórz oczy, już nie żyjesz, [w:] eadem, Gra na wielu bębenkach. 19 opowiadań, Wałbrzych 2001, s. 8.

29 Eksperyment, rozmowa Agnieszki Sowińskiej z Jackiem Dehnelem i Piotrem Tarczyńskim, [w:] „Dwutygodnik.com”, [źródło internetowe] https://www.dwutygodnik.com/artykul/6039-eksperyment.html, dostęp: 15.01.2020.
} 


\section{BIBLIOGRAFIA}

Chłosta-Zielonka Joanna. 2013. Zamiast powieści obyczajowej. Cechy współczesnej polskiej powieści sensacyjnej. „Media - Kultura - Komunikacja Społeczna” nr 9: 87-98.

Eco Umberto. 2008. Superman $w$ literaturze masowej. Powieść popularna między retoryka a ideologia. Przeł. J. Ugniewska. Kraków: Wydawnictwo Znak.

Jaskot Maciej, Ganoshenko Jurii. 2017. Lwów jako konstrukt nostalgiczny polskiego i ukraińskiego kryminału retro. W: 50 twarzy popkultury. Red. Olkusz K. Kraków: Ośrodek Badawczy Facta Ficta: 603-621. W: https://www.researchgate.net/publication/318672970_Lwow_jako_konstrukt_nostalgiczny_polskiego_i_ukrainskiego_ kryminalu_retro [dostęp: 31.03.2020].

Kaczyński Paweł. 2014. Kryminat historyczny - próba poetyki. W: Śledztwo w sprawie gatunków. Literatura kryminalna. Red. Gemra A. Kraków: Wydawnictwo EMG: 191-209.

Kietlińska Elżbieta. 2012. Wrażenia $i$ wspomnienia młodej teatromanki. Wstęp i oprac. Michalik J. Bibliotheca Jagiellonica. Fontes et Studia 23. Kraków: Księgarnia Akademicka.

Kosmala Małgorzata. 2011. Kryminalne retroświaty. W: Przerabianie XIX wieku. Red. Paczoska E., Szleszyński B. Warszawa: Państwowy Instytut Wydawniczy: 223-245.

Mazurkiewicz Adam. 2014. Tendencje rozwojowe współczesnej literatury kryminalnej. W: Śledztwo w sprawie gatunków. Literatura kryminalna. Red. Gemra A. Kraków: Wydawnictwo EMG: 151-176.

Sowińska Agnieszka, Dehnel Jacek, Tarczyński Piotr. Eksperyment. W: https://www.dwutygodnik.com/artykul/6039-eksperyment.html [dostęp: 15.01.2020].

Steckiewicz Martyna. 2014. Czas przeszty dokonany? Obraz międzywojnia w kryminałach retro. W: Śledztwo w sprawie gatunków. Literatura kryminalna. Red. Gemra A. Kraków: Wydawnictwo EMG: 247-261.

Szymiczkowa Maryla. 2015. Tajemnica Domu Helclów. Kraków: Wydawnictwo Znak Literanova.

Szymiczkowa Maryla. 2016. Rozdarta zasłona. Kraków: Wydawnictwo Znak Literanova.

Szymiczkowa Maryla. 2018. Seans w Domu Egipskim. Kraków: Wydawnictwo Znak Literanova.

Wajda Katarzyna. Śladem retrozbrodni. W: https://www.dwutygodnik.com/artykul/3820-sladem-retrozbrodni.html [dostęp: 15.01.2020].

Wróblewska Violetta. 2011. Tendencje rozwojowe polskiej literatury kryminalnej po 1989 roku. „Acta Universitatis Wratislaviensis. Literatura i Kultura Popularna” XVII: $127-$ 145.

\section{MŁODOPOLSKIE KRYMINAŁY Z GALICJĄ W TLE, CZYLI MARYLI SZYMICZKOWEJ SPOSÓB NA KRYMINAŁ RETRO}

Streszczenie: Kryminały retro, których akcja rozgrywa się na przełomie wieków XIX i XX albo w latach międzywojennych, tworzą obecnie jeden $\mathrm{z}$ najpopularniejszych nurtów literatury kryminalnej w Polsce. Wśród ciekawszych zjawisk literackich ostatnich lat należy odnotować ukazujący się pod pseudonimem Maryli Szymiczkowej krakowski cykl kryminałów retro autorstwa Jacka Dehnela i Piotra Tarczyńskiego. Celem niniejszego artykułu jest analiza fenomenu powieściowej trylogii: Tajemnica Domu Helclów (2015), Rozdarta zasłona (2016) i Seans w Domu Egipskim (2018), która wpisuje się w czytelni- 
czą koniunkturę powieści kryminalnych osadzonych w dawnej przeszłości, a równocześnie gra z popkulturową konwencją, obficie czerpiąc z różnorodnych źródeł literackich, wskrzeszając malowniczy obraz kultury modernizmu wraz z historyczno-obyczajowymi realiami dziewiętnastowiecznej Galicji.

Słowa klucze: kryminał retro, Maryla Szymiczkowa, Jacek Dehnel, Piotr Tarczyński

\section{ГАЛИЧИНА В МОЛОДОПОЛЬСЬКИХ ДЕТЕКТИВНИХ РОМАНАХ, АБО МАРИЛИ ШИМІЧКОВОЇ СПОСІБ НА РЕТРО-ДЕТЕКТИВ}

Резюме: Ретро-детективи, дія яких розгортається на зламі XIX та XX століть або в міжвоєнний період, зараз стали одними із найпопулярніших в польській кримінальній літературі. Серед найцікавіших літературних подій останніх років слід відзначити краківську серію ретро-детективів Яцека Денеля та Піотра Тарчинського, що друкуються під псевдонімом Марила Шимічкова. Метою даної статті є аналіз феномену романної трилогіі: Tajemnica Doти Helclów (Таємниия будинку Гельилів, 2015), Rozdarta zasłona (Роздерта завіса, 2016) та Seans w Domu Egipskim (Cеанс в Сгипетському домі, 2018). Згадана серія романів не лише добре вписується в читацьку кон'юнктуру детективів, побудованих на минулому, вона також грає з конвенцією поп-культури, щедро черпаючи з різноманітних літературних джерел та відроджуючи мальовничий образ культури Модернізму з її історичними та побутовими реаліями Галичини XIX століття.

Ключові слова: ретро-детектив, Марила Шимічкова, Яцек Денель, Піотр Тарчинські 
